\title{
Marcin Graban
}

Adam Mickiewicz University in Poznań

Institute of History

e-mail: mgraban@amu.edu.pl

\section{Kwestia robotnicza w USA w I pol. XX w. Wkład Kościoła katolickiego w jej rozwiązanie}

\section{The Labour Question in the USA in First Half of $20^{\text {th }}$ Century. Contribution of the Catholic Church to Its Solution}

The problems of workers' wages taken by the Catholic Church in the United States of America are interesting issues from the point of view of the ethics of economic life and the development of Catholic social thought. The interpretation of the main Catholic social ideas contained in Leo XIII's encyclical letter Rerum novarum was made by Father John Augustine Ryan (1896-1945), who soon became a major proponent of the idea that a good economic policy can flow only with good ethics. In the history of the United States of America, the turn of $19^{\text {th }}$ and $20^{\text {th }}$ centuries was a time of the development of labor unions, associations, and workers' organizations, consolidating efforts to achieve equitable remuneration (a living wage) and regulate working conditions. It was also a time of struggling with the ideas of socialism and nationalism. The Catholic Church played a significant role in the discourse on these issues, including the influence of John A. Ryan. His efforts led to one of the most important interpretations of economic life: The Program of Social Reconstruction (1919), and some postulates can be found in the legislation of the New Deal.

Keywords: John. A. Ryan, Catholic social thought in the USA, wages, labor conditions

JEL Classification: B31, J31 


\section{Wprowadzenie}

Podjęcie problemu wynagrodzeń robotniczych przez Kościół katolicki ${ }^{1}$ w Stanach Zjednoczonych Ameryki jest interesującą kwestią z punktu widzenia etyki życia gospodarczego oraz rozwoju katolickiej nauki społecznej. Interpretację katolickiej myśli społecznej zawartej w encyklice Rerum novarum Leona XIII podjął na terenie Stanów Zjednoczonych ksiądz John Augustine Ryan (1869-1945). Stał się on głównym propagatorem idei, że dobra polityka ekonomiczna może wypływać tylko z dobrej etyki.

Przełom XIX i XX w. to w historii Stanów Zjednoczonych Ameryki czas rozwoju związków i organizacji robotniczych, utrwalania się dążeń do godziwego wynagrodzenia (living wage) i regulacji warunków pracy. Jest to również czas zmagania się z ideami socjalistycznymi i nacjonalistycznymi. Kościół katolicki odegrał znaczącą rolę $\mathrm{w}$ dyskursie dotyczącym tych problemów; duża w tym zasługa Johna A. Ryana. Jedną z ważniejszych interpretacji życia gospodarczego był Program of Social Reconstruction, przygotowany przez biskupów amerykańskich w 1919 roku. Stał się on istotnym głosem w kwestii stosunków społecznych, nawiązującym do przesłania Rerum novarum. Pewne elementy głoszonych postulatów można odnaleźć w ustawodawstwie okresu New Deal. Celem niniejszej publikacji jest prześledzenie drogi wprowadzania nowych idei na gruncie stosunków pracy i ich praktycznego zastosowania w postaci ustawodawstwa New Deal. Do zrealizowania tego celu posłuży nam głównie dorobek księdza Johna A. Ryana, który był prekursorem wprowadzania na terenie Stanów Zjednoczonych idei zawartych w Rerum novarum. Za początek rozwoju katolickiego nauczania społecznego w tym kraju przyjmuje się jego dysertację doktorską z 1906 r., która została opublikowana pod tytułem A Living Wage. It's Ethical and Economic Aspects ${ }^{2}$.

Ze względu na cel pracy cezura czasowa obejmuje lata 1906 - 1937. Wyznacza ją podjęcie kwestii społecznych oraz próba interpretacji encykliki Rerum novarum przez Johna A. Ryana. Data końcowa odnosi się do realizacji ustaw New Deal, postrzeganych jako prób wprowadzenia katolickich postulatów do życia społecznego.

Pojęcie living wage, jako postulat wyższych wynagrodzeń dla robotników, pojawiło się już na początku XIX w. Living wage to wynagrodzenie powyżej minimum egzystencji, które rodzinie robotnika zapewni utrzymanie na odpowiednim poziomie. Powinno ono obejmować, oprócz zapewnienia podstawowych potrzeb egzystencjalnych: jedzenie, odzież, schronienie, również możliwości rozwoju społecznego i ekonomicznego, czyli m.in. wydatki na kulturę i edukację.

\footnotetext{
${ }^{1}$ W pracy termin Kościół katolicki i Kościół odnoszą się do Kościoła rzymskokatolickiego. Autor ma świadomość występowania na terenie Stanów Zjednoczonych Ameryki innych kościołów katolickich, np. Polskiego Narodowego Kościoła Katolickiego, jednak taka forma sprzyja przejrzystości tekstu.

${ }^{2}$ Cf. P.J. Sullivan, Catholic Labor Priests in the United States. A $20^{\text {th }}$ Century Story of Solidarity, vol. 1, Five Giants in the Bishops' Social Action Department Among More Than Four Hundred U.S. Catholic Labor Priests, Pacem in Terris Press, Washington D.C. 2014, s. 7.
} 
Współczesna definicja funkcjonująca na terenie USA obejmuje wydatki na: mieszkanie, jedzenie, transport, opiekę medyczną, podatki i opiekę nad dziećmi, które znacznie przekraczają federalne i stanowe płace minimalne ${ }^{3}$.

Problem wynagrodzeń, stawek godzinowych, wreszcie tzw. dochodu podstawowego (jako świadczenia wypłacanego przez państwo bez względu na świadczenie pracy) jest obecnie przedmiotem intensywnej dyskusji; między innymi rozważa się wprowadzenie dla wszystkich obywateli świadczenia, które ma stanowić alternatywę dla coraz bardziej rozbudowywanych systemów socjalnych. Zakłada się, że będzie to znacznie tańsze rozwiązanie. Obecnie jest ono przedmiotem rozważań w Finlandii (program eksperymentalny na niewielkiej grupie obywateli przeprowadzono w 2017 r.) i Szwajcarii (referendum odbyło się w czerwcu 2016 r.). Również w Polsce rządowy projekt wprowadzenia minimalnej stawki godzinowej $(13 \mathrm{zł} / \mathrm{h})$ rozbudził dyskusję na temat warunków płacowych i przyszłości stosunków pracy ${ }^{4}$. Oczywiście trudno porównywać dzisiejszą dyskusję z tą prowadzoną na przełomie XIX i XX w. w Stanach Zjednoczonych Ameryki, jednak zainteresowanie tematem pozwala sądzić, że refleksja historyczna może być ciekawym przypomnieniem wypracowanych już rozwiązań i propozycji poprawy warunków płacowych robotników.

\section{Kwestia robotnicza a Kościół katolicki w Stanach Zjednoczonych Ameryki}

Sytuacja materialna amerykańskich robotników była bardzo zróżnicowana i zależała od wielu czynników. Można wyróżnić podstawowy podział robotników ze względu na dwie kategorie - pochodzenie i kwalifikacje zawodowe. Pracownicy wykwalifikowani jako pierwsi wywalczyli sobie prawo do 10-godzinnego dnia pracy (w 1835 r.) i podwyżki do 50\% dziennego wynagrodzenia (w latach 18361837) z 1-1,20 \$ do 1,50-2 \$5. Na sytuację pracowników niewykwalifikowanych (głównie imigrantów) w dalszym ciągu wpływ miały wahania koniunktury i często pracowali oni tylko w określone dni w tygodniu. 10-godzinny dzień pracy dla wszystkich robotników wprowadzono w 1874 r. w stanie Massachusetts ${ }^{6}$. Zróżnicowanie płac pomiędzy robotnikami wykwalifikowanymi i niewykwalifikowanymi było bardzo duże: w 1882 r. średnie dzienne wynagrodzenie robotnika wykwa-

\footnotetext{
${ }^{3}$ S. Luce, Living Wage Policies and Campaigns: Lessons from the United States, „International Journal of Labour Research" 2012, vol. 4, nr 1, s. 12.

${ }^{4}$ Cf. m.in. A. Leszczyński, Pieniądze za nic, „Polityka” 2015, nr 14, s. 53-55.

${ }^{5}$ J.G. Rayback, A History of American Labor. Expanded and Updated, The Free Press, New York 1966, s. 77.

${ }^{6}$ S.S. Whittelsey, Massachusetts Labor Legislation [w:] Trade Unionism and Labor Problems, red. J.R. Commons, Ginn and Co., Boston, New York, Chicago, London, 1905, s. 483.
} 
lifikowanego w fabryce wynosiło ok. 3,50 \$, robotnika niewykwalifikowanego zaś ok. 1,25 \$; średnie zarobki w fabryce kształtowały się na poziomie $3 \$^{7}$. Średnie roczne wynagrodzenie wynosiło odpowiednio ${ }^{8}$ :

$$
\begin{aligned}
& 1865-1869-347 \$ \\
& 1875-1879-395 \$ \\
& 1885-1889-503 \$ \\
& 1895-1899-532 \$ \\
& 1901-1905-606 \$ \\
& 1911-1915-685 \$ .
\end{aligned}
$$

Charakter pracy rozróżniano także ze względu na płeć. Kobiety zatrudniano najchętniej jako służbę domową, w przemyśle włókienniczym, odzieżowym i spożywczym. Pomiędzy rokiem 1880 a 1910 odsetek kobiet w ogólnej liczbie zatrudnionych wzrósł z $15 \%$ do $20 \%$, a w okresie I wojny światowej zatrudniono dodatkowo ok. miliona kobiet ${ }^{9}$. Wśród mężczyzn istniały preferencje dotyczące poszczególnych nacji, np.: Irlandczycy i Chińczycy pracowali masowo w budownictwie, Włosi, południowi Słowianie i Meksykanie przy budowie kolei. Polacy chętnie zatrudniali się w przemyśle ciężkim (w stalowniach, hutach, górnictwie), Niemcy w piekarniach i browarach, Francuzi z Kanady oraz część Włochów w fabrykach obuwia. Dodatkowo poszczególne grupy wybierały odpowiednie rejony Stanów Zjednoczonych, aby się tam osiedlać ${ }^{10}$.

Stopniowa poprawa warunków materialnych nie rekompensowała w pełni trudnych warunków pracy. Szczególnie jeżeli pracownicy uzależnieni byli od sprawności i wydajności maszyn, a system pracy zakładał tzw. piecework (praca na akord):

Po ślubie mój mąż nigdy zbytnio nie rozmawiat o swojej pracy [w Pittsburgh Steel Company w Monessen]. Po prostu pewnego dnia maszyny nie pracowaly i nie mógt nic zrobić, ponieważ pracowat na akord. Maszyna często mu się psuta. Byli specjalni mechanicy od maszyn, jeśli jednak byli zajęci naprawa innej

\footnotetext{
${ }^{7}$ I.A. Hourwich, Immigration and Labor. The Economic Aspects of European Immigration to the United States, G.P. Putnam's Sons, New York, London 1912, s. 283.

Dla porównania średnie zarobki polskich imigrantów wynosiły w 1. 1880-1914 od 1 \$ do $3.50 \$$ dziennie, a rocznie średnio ok. 573 \$. Cf. A. Walaszek, Polscy robotnicy, praca i związi zawodowe w Stanach Zjednoczonych Ameryki, 1880-1922, Ossolineum, Wrocław-Warszawa-Kraków-GdańskŁódź, 1988, s. 37.

${ }^{8}$ H.N. Scheiber, H.G. Vatter, H.U. Faulkner, American Economic History, Harper and Row, New York 1976, s. 247.

Obliczeń dokonano według wartości nabywczej dolara w 1914 r. Należy jednak pamiętać, że do wzrostu płac przyczyniły się także inflacja i wyższe koszty życia.

${ }^{9}$ Ibidem, s. 248, 323.

${ }^{10}$ D.R. Gabaccia, Imigracja do Stanów Zjednoczonych, 1848-1917 [w:] Historia Stanów Zjednoczonych Ameryki, t. 3 (1848-1917), red. W. Nugent, H. Parafinowicz, PWN, Warszawa 1995, s. 195-196.
} 
maszyny, mój mąż musiał czekać i przez to tracił czas. Czasem więc pracował za 10-12 dolarów, kiedy mógł zarobić 16-18 dolarów. To była jedyna rzecz, na którą się skarży $t^{11}$.

Podporządkowanie rytmu pracy człowieka sprawności maszyny budziło zrozumiałe frustracje, szczególnie gdy praca przy niej była wyjątkowo przykra.

Maszyny byty okropnie brudne od oleju. Pamiętam, gdy kupiłam mu [mężowi] parę butów, byt szczęśliwy, gdy mógt w nich pracować przez trzy miesiace. Później byty przesiaknięte olejem. Olej pryskat z tych maszyn ${ }^{12}$.

Osobnym problemem była praca dzieci. Nie była ona prawnie zabroniona, podlegała jednak pewnym ograniczeniom, początkowo polegającym jedynie na zakazie obsługi przez dzieci zbyt skomplikowanych maszyn. W 1903 r. The Factory Child Act ustanawiał, że dzieci poniżej 14. roku życia mogły pracować na powietrzu (tzn. poza obszarem hal fabrycznych), dodatkowo ustalono, że czas pracy dzieci poniżej 12. roku życia nie może być dłuższy niż 6 godzin (dotyczyło to tylko stanu Nowy Jork ${ }^{13}$. Władze federalne uznały, że najlepszym sposobem rozwiązania tego problemu będzie wprowadzenie obowiązku szkolnego. Dynamiczny rozwój systemu edukacji spowodował, że między rokiem 1870 a 1900 liczba uczniów szkół publicznych wzrosła ponad dwukrotnie ${ }^{14}$.

Sytuacją robotników zainteresował się Kościół katolicki w Stanach Zjednoczonych Ameryki, który rozwijał się za sprawą napływu imigrantów z Europy Środkowej i Południowej. W latach 1890-1920 liczba wiernych wzrosła z 9 do $18 \mathrm{mln}^{15}$. Gwałtowny przyrost społeczności katolickiej skutkował potrzebą tworzenia instytucji, które mogłyby wspierać nowo przybyłych imigrantów. Powodowało to olbrzymie wydatki. Problemy społeczne, rodzące się wraz z narastającą falą imigrantów, stały się dla biskupów amerykańskich palącym zagadnieniem. Pierwszy zareagował na to bp John Hughes (biskup koadiutor Nowego Jorku od 1838 r.). Uznał on, że biskupi jako powiernicy majątku kościelnego muszą dbać o to, aby zabezpieczyć środki finansowe na wszystkie potrzeby wiernych, zwłaszcza tych, którzy nie mogą sami o siebie zadbać. Biskup Hughes był przekonany o potrzebie poznania i zrozumienia mechanizmów ekonomicznych, ponieważ mają one istotny wpływ na życie społeczności. Doszedł do wniosku, że ekonomię polityczną należy dopasować do realiów danego kraju, ponieważ to właśnie ona motywuje jednostki do działania. Kościół nie może tego zbagatelizować. Bp Hughes dążył, aby Kościół stał się pośrednikiem pomiędzy poszczególnymi grupami interesów: właścicielami ziemskimi a robotnikami rolnymi oraz przemysłowcami a robotnikami. $\mathrm{W}$ ten sposób miałby szansę wprowadzić w relacjach między nimi

\footnotetext{
${ }^{11}$ Relacja Rose Popovich [w:] Workers' World. Kinship, Community, and Protest in an Industrial Society 1900-1940, red. J. Bodnar, John Hopkins Univ. Press, Baltimore 1982, s. 50.

12 Ibidem, s. 50.

${ }^{13}$ Ibidem, s. 61.

${ }^{14}$ H.U. Faulkner, American Political and Social History, Houghton Mifflin, New York 1943, s. 473.

${ }^{15}$ Z. Lewicki, Historia cywilizacji amerykańskiej. Era konsolidacji 1861-1945, Wyd. Naukowe Scholar, Warszawa 2012, s. 292.
} 
ducha chrześcijańskiej sprawiedliwości ${ }^{16}$. Opór wobec sprowadzania imigrantów katolików związany był m.in. z kwestią lojalności wobec Państwa Kościelnego i papieża, co uznawano za sprzeczne z lojalnością wobec państwa amerykańskiego. Postępowy odłam episkopatu amerykańskiego z arcybiskupem Johnem Irelandem i kardynałem Jamesem Gibbonsem starał się udowodnić absurdalność tych zarzutów. Wystąpienie abpa Irelanda na III Synodzie Plenarnym w Baltimore w 1884 r. było próbą obrony amerykańskich katolików przed zarzutami nielojalności wobec liberalnych ideałów (zarówno politycznych, jak i ekonomicznych) demokracji amerykańskiej. Było również jednym z pierwszych, w którym podjęto kwestię społeczną oraz zagadnienie stosunku Kościoła do instytucji państwowych. Abp Ireland wskazał m.in. na brak sprzeczności między wiarą katolicką a lojalnością wobec państwa ${ }^{17}$. Należy pamiętać, że w Stanach Zjednoczonych rozdzielność państwa i Kościoła, zaakcentowana w Pierwszej Poprawce do Konstytucji Stanów Zjednoczonych, jest jedną z najważniejszych podstaw państwowości ${ }^{18}$. Ryszard M. Małajny dokonał wyliczenia zasad w stosunkach państwo - Kościół w Stanach Zjednoczonych, wynikających z Pierwszej Poprawki. Są to: separacjonizm, równość, dobrowolność, nieingerencja państwa w sprawy religii, akomodacja państwa, wzajemne powstrzymywanie się państwa i Kościoła, współpraca państwa i Kościoła, neutralność państwa ${ }^{19}$.

Istotnymi problemami robotników zajmowały się również związki zawodowe sprzyjające Kościołowi i katolikom imigrantom, m.in. Rycerze Pracy i Amerykańska Federacja Pracy. Popierały one postulowany przez encyklikę Rerum novarum program zachęcania robotników do oszczędzania i inwestowania w akcje lub wręcz przekazywania nieodpłatnie robotnikom części akcji zatrudniających ich przedsiębiorstw. Pomysł uznano za dobry, ponieważ, jak przewidywał Leon XIII, miał on zapobiec strajkom, czyniąc robotników współwłaścicielami przedsię-

\footnotetext{
${ }^{16}$ J.P. Chinnici, Spiritual Capitalism and the Culture of American Catholicism, „U.S. Catholic Historian” 1986, vol. 5, nr 2, s. 149-151.

${ }^{17}$ J. Ireland, The Catholic Church Equally Opposed to Anarchy and to Despotism, the Guardian of Society, the Defender of True Liberty [w:] The Memorial Volume. A History of the Third Plenary Council of Baltimore (November 9 - December 7, 1884), The Baltimore Publishing Co., Baltimore 1885, s. 11-32. [tytuł nad artykułem nie jest taki sam jak tytuł widniejący w spisie treści i brzmi: The Church - the Support of Just Government].

${ }^{18}$ Pierwsza Poprawka do Konstytucji Stanów Zjednoczonych brzmi: Kongres nie może stanowić ustaw wprowadzajacych religię albo zabraniajacych swobodnego wykonywana praktyk religijnych, ograniczajacych wolność słowa albo prasy, albo naruszających prawo do swobodnych zgromadzeń $i$ do wnoszenia do najwyższych władz petycji o naprawienie krzywd. Cyt. za: Konstytucja Stanów Zjednoczonych Ameryki, wstęp i tłum. M. Król-Bogomilska, Beartig, Warszawa 1992, s. 37.

Na temat rozdziału Kościoła i państwa w USA, cf.: P. Napierała, In God We Trust. Religia w sferze publicznej USA, Księgarnia Akademicka, Kraków 2015, s. 105-110.

${ }^{19}$ R.M. Małajny, „Mur separacji” - państwo a Kościót w Stanach Zjednoczonych Ameryki, Wyd. Uniwersytetu Śląskiego, Katowice 1992, s. 270.

Na następnych stronach autor szczegółowo objaśnia praktyczne działanie tych zasad. Co więcej, J. Chałasiński podkreśla, że konstytucyjna zasada tolerancji religijnej leży u podstaw jedności kulturowej społeczeństwa amerykańskiego. Cf. J. Chałasiński, Kultura amerykańska. Formowanie się kultury narodowej w Stanach Zjednoczonych Ameryki, Ludowa Spółdzielnia Wydawnicza, Warszawa 1970, s. 577.
} 
biorstw, a zatem współodpowiedzialnymi za ich rozwój i powodzenie. Powszechnie wprowadzono go w życie w 1920 r. Jednak, jak obliczyła Federal Trade Commission, do 1922 r. zaledwie 7,5\% akcji trafiło w ręce robotników ${ }^{20}$.

\section{Działalność Johna A. Ryana}

John A. Ryan (1869-1945) urodził się w miasteczku Vermillion niedaleko St. Paul w stanie Minnesota, jego rodzice byli imigrantami z Irlandii. W 1892 r. ukończył St. Thomas College w St. Paul. Święcenia kapłańskie otrzymał po ukończeniu (w 1898 r.) archidiecezjalnego Seminarium Duchownego w St. Paul z rąk abpa Johna Irelanda. Po otrzymaniu święceń został wysłany na Amerykański Uniwersytet Katolicki w Waszyngtonie, gdzie studiował teologię moralną ${ }^{21}$. Po studiach (w 1902 r.) powrócił do seminarium w St. Paul jako nauczyciel teologii moralnej. W 1906 r. ks. Ryan obronił doktorat z teologii ${ }^{22}$. Pozostał nauczycielem w seminarium. W tym czasie pracował nad książką A Living Wage ${ }^{23}$. Dzięki niej ks. Ryan został powołany (w 1915 r.) na stanowisko profesora teologii moralnej na Amerykańskim Uniwersytecie Katolickim. Funkcję tę sprawował aż do przejścia na emeryturę w 1939 r. Jednocześnie nauczał w Trinity College, był przewodniczącym Social Action Department w National Catholic Welfare Conference oraz redagował czasopismo Catholic Charities Review ${ }^{24}$.

Sprawowanie tak wielu funkcji sprawiło, że ks. Ryan stał się największym propagatorem idei katolickiej działalności społecznej. Z czasem przylgnął do niego tytuł Right Reverend New Dealer ${ }^{25}$. Potrafił wykorzystać teologię moralną do rozstrzygania dylematów społeczno- i polityczno-ekonomicznych. Ze swoich spostrzeżeń wyciągnął prosty wniosek: z dobrej etyki wyniknąć może tylko dobra polityka ekonomiczna ${ }^{26}$. Samo spostrzeżenie było jednak niewystarczające, trzeba było wprowadzić praktyczne rozwiązania, aby osiągnąć zamierzony cel. Ryan powrócił do źródła nowoczesnej katolickiej nauki społecznej - encykliki Rerum novarum Leona XIII. Stał się jej gorliwym propagatorem i odczytał ją w kontek-

\footnotetext{
${ }^{20}$ Brak danych, czy odsetek ten dotyczył liczby czy wartości akcji. H.U. Faulkner, M. Starr, Labor in America, Oxford Book Co., New York 1958, s. 175-176.

${ }^{21}$ J.M. McShane, Sufficiently Radical. Catholicism, Progressivism, and the Bishops' Program of 1919, Catholic Univ. Press, Washington 1986, s. 26-27.

22 J.A. Ryan, A Social Doctrine in Action. A Personal History, Harper and Brothers, New York, London 1941, s. 78-79.

${ }^{23}$ Książka J.A. Ryana A Living Wage ukazała się nakładem wydawnictwa Macmillan (New York) w 1909 r. Następnie w 1910 r. ukazały się francusko- i hiszpańskojęzyczne przekłady tej pracy. Cf. ibidem, s. 82 .

${ }^{24}$ J.M. McShane, op. cit., s. 27.

${ }^{25}$ Wiązało się to ze współpracą ks. Ryana z instytucjami powołanymi w ramach New Deal, np. z National Recovery Administration. F.L. Broderick, Right Reverend New Dealer: John A. Ryan, Macmillan \& Co., New York 1963, s. 213, 227.

${ }^{26}$ R.J. Purcell, John A. Ryan. Prophet of Social Justice, „Studies” 1946, June, s. 154-157, American Catholic History Research Center and University Archives, The Catholic University of America Washington D.C. (dalej: ACUA) John A. Ryan Collection, Box 58 (Reference File Series), folder 15 (Biographical articles).
} 
ście sytuacji społeczno-ekonomicznej w Stanach Zjednoczonych. Tłumaczył i wyjaśniał możliwości jej zastosowania, stał się pierwszym profesorem na Katolickim Uniwersytecie Amerykańskim, który nauczał ekonomii jako integralnej wiedzy niezbędnej każdemu duchownemu ${ }^{27}$. Ryan, uzasadniając potrzebę studiowania $\mathrm{w}$ seminariach wiedzy na temat społeczeństwa, stwierdził, że jest ona konieczna, ponieważ dodaje wiarygodności posłudze kapłańskiej. Wiedza ta jest księżom niezbędna do pracy w środowiskach robotniczych i do rozwiązywania ich problemów, także społecznych ${ }^{28}$.

W rozważaniach nad kwestią społeczną John A. Ryan wyszedł od podstaw wiary katolickiej:

Glównym interesem $w$ życiu, w oczach katolika, jest ocalenie jego nieśmiertelnej duszy. Życie człowieka na ziemi trwa tylko kilka krótkich lat; jego życie pozagrobowe jest nieskończone. Jakość tego życia po śmierci zależy, w każdym z przypadków, od sposobu, w jaki spędził swoje ziemskie życie, i od relacji, w jakiej byt wobec Boga w chwili śmierci. Jeżeli umart pojednany ze swoim Stwórca, zostanie prędzej czy później przeznaczony do nieskończonego szczęścia; jeżeli umrze we wrogości do Boga, zostanie skazany na wieczne potępienie. Stąd podstawowym czynnikiem dla każdego rozumnego człowieka jest taka egzystencja, która doprowadzi go do szczęścia po śmierci. Jego doczesne życie jest ważne tylko ze względu na czas decydujący o tym, czy będzie szczęśliwy czy potępiony $w$ przyszłym życiu. Dlatego ziemskie szczęście $i$ bogactwo człowieka jest sprzeczne z jego wiecznym interesem, na którego korzyść trzeba zdecydować zawczasu ${ }^{29}$.

Doprowadziło to do uznania, za nauczaniem Leona XIII, kwestii społecznej za problem religii i moralności, ponieważ każda ludzka aktywność jest z natury rzeczy w kręgu zainteresowań Kościoła ${ }^{30}$. Zastrzeżenie takie w polemice Ryana było niezbędne, aby nie tłumaczyć za każdym razem swoich praw do podnoszenia kwestii społecznej przed socjalistami, którzy uznawali, że religia nie ma w rozstrzyganiu tych problemów prawa głosu.

Kościół dysponował różnymi metodami ingerowania w sytuację robotników. Ryan określił je następująco:

Sa trzy podstawowe drogi, którymi autorytet Kościoła może właściwie ogarnać doświadczeniem relacje dotyczace kapitatu i przemystu: przez stosowanie podstaw moralności do poszczególnych praktyk ekonomicznych; przez napomnienia

\footnotetext{
${ }^{27}$ A.I. Abell, Monsignor John A. Ryan: An Historical Appreciation, „The Review of Politics” 1946, vol. 8, nr 1, s. 130, ACUA John A. Ryan Collection, Box 58 (Reference Files Series), folder 15 (Biographical articles).

${ }_{28}$ J.A. Ryan, The Study of Social Problems in the Seminary, „Proceedings of the Catholic Educational Association" 1908, s. 446, ACUA John A. Ryan Collection, Box 62 (Writings, Speeches and Sermon Series 1900-1919), folder 10.

${ }^{29}$ Catholicus [John A. Ryan], A Catholic View of Socialism, „International Socialist Review” 1901, October, kopia, ACUA John A. Ryan Collection, Box 62 (Writings, Speeches and Sermon Series), folder 9 .

${ }^{30}$ J.A. Ryan, Church and Economic Problems, maszynopis, ACUA John A. Ryan Collection, Box 62 (Writings, Speeches and Sermons Series), folder 16.
} 
opinii o moralności poszczególnych metod lub środków reform; przez wspieranie i namawiane do przyjęcia pewnych metod i środków. Wszystkie wielkie encykliki $i$ inne deklaracje papieża na temat kwestii społecznej sa przyktadami tych trzech form ,wynalazków"31.

Wszystkie metody są jednak zakotwiczone w nauce moralnej.

Określenie, jaki w nauczania Ryana był stosunek do socjalistów, stanowi pewien problem. Dopóki socjaliści atakowali Kościół i jego podejście do kwestii społecznych, dialog był znacznie utrudniony. Jednak Ryan go nie wykluczał. Dwa podstawowe postulaty ekonomiczne socjalistów to wspólne posiadanie i zarządzanie środków produkcji oraz kolektywna dystrybucja dóbr. Pierwszy z nich, mimo iż niepraktyczny (tak uważał Ryan), nie był zły, ponieważ pracownicy mogliby posiadać i wspólnie zarządzać przedsiębiorstwem, w którym są zatrudnieni. Takie rozwiązanie Ryan uważał za zgodne ze sprawiedliwością katolicką, o ile każdy z pracowników posiadałby część np. akcji przedsiębiorstwa jako swoją nienaruszalną własność. Drugi postulat socjalistów, dotyczący kolektywnej dystrybucji dóbr, Ryan odrzucił, ponieważ uważał, że doprowadziłoby to do nadużyć ${ }^{32}$. Zatem zasadnicza kwestia polegała na tym, że popierał on koncepcję własności publicznej, która nie musiała od razu oznaczać socjalizmu ${ }^{33}$. Ryan dążył do wprowadzenia reform socjalnych, ale nie socjalistycznych ${ }^{34}$. Mimo jego jasnych intencji oskarżano go o zbyt lewicowe poglądy. Domagał się nowoczesnej i otwartej debaty na temat warunków życia, pracy i potrzeb robotników. Otwarta dyskusja dawała robotnikom prawo do zaprezentowania swoich potrzeb i oczekiwań oraz skonfrontowania ich z propozycjami pracodawców. Miało to sprzyjać sprawiedliwemu rozstrzyganiu konfliktów i było znacznie lepsze niż rozwiązania siłowe, np. strajki.

Najistotniejszym punktem rozważań Ryana było podjęcie kwestii tzw. living wage. Pojęcie to określało poziom wynagrodzenia, jakie powinien otrzymać pracownik, aby godnie żyć i utrzymać rodzinę. Zdefiniował je tak:

Krótko definiując living wage - jest to płaca odpowiednia dla godziwej egzystencji. Jest to kwota wynagrodzenia, która zabezpieczy robotnikowi dochód godny dla czlowieka. Koncepcja living wage oraz przyzwoitego poziomu utrzymania jest u swoich podstaw bardziej moralna anizeli fizyczna czy ekonomiczna. Pojmuje robotnika jako osobę, jako niemal święta jednostkę, posiadajaca wrodzona wartość, jako skończoność sama w sobie. Pracownik nie zostat wymyślony jako zaledwie przedmiot dla innej jednostki ani jako jakiś cel lub interes spoteczny. Jest osoba moralnie zobowiąana $i$ moralnie uprzywilejowana do realizowania własnej doskonałości, do rozwoju własnej osobowości, do życia rozsadnym ludzkim życiem. Dla tych celów musi posiadać środki do doskonalenia i rozwoju wszystkich zdolności fizycznych, mentalnych, moralnych i duchowych.

\footnotetext{
${ }^{31}$ Idem, The Church and the Social Question, maszynopis, ACUA John A. Ryan Collection, Box 63 (Writings, Speeches and Sermons Series), folder 16.

${ }^{32}$ Catholicus [John A. Ryan], op. cit.

${ }^{33}$ J.A. Ryan, The Catholic Church and Public Ownership, maszynopis, ACUA John A. Ryan Collection, Box 63 (Writings, Speeches and Sermons Series, 1910-1928), folder 2.

${ }^{34}$ Idem, The Church and the Radical Social Movements, maszynopis, ACUA John A. Ryan Collection, Box 63 (Writings, Speeches and Sermons Series), folder 3.
} 
Do jakiego poziomu? Cóż, do pewnego poziomu, rozsadnego poziomu, do takiego wreszcie poziomu, który jest niezbędny do prowadzenia życia jako istota ludzka, a nie jak koń czy świnia. Przynajmniej na tyle, na ile obejmuje to idea godnego życia ${ }^{35}$.

Ryan określił średnie wynagrodzenie, które zapewniłoby godziwy byt rodziny w Stanach Zjednoczonych w 1910 r., w małych i średnich miastach na poziomie ok. 700 \$ rocznie; w wielkich miastach ok. 800-900 \$ rocznie. Obliczył, że w stanie Massachusetts jedynie ok. 25\% rodzin robotników spełnia takie kryteria zarobkowe i to tylko przy założeniu, że robotnicy znajdują stałe zatrudnienie i pracują przez cały rok $^{36}$. Do tych obliczeń można dodać, że średnie zarobki imigrantów były zazwyczaj o ok. 25\% niższe od zarobków rodowitych Amerykanów. Należało zatem wprowadzić prawo regulujące wysokość zarobków tak, aby nie były one uzależnione od pochodzenia robotników. Jeżeli to koniecznie, postulował ograniczenie imigracji i dostosowanie jej do tempa rozwoju gospodarczego ${ }^{37}$.

W uregulowaniu tych problemów niezbędna była inicjatywa państwa. Ryan, wspominając nauczanie Leona XIII zawarte w Rerum novarum, przypomniał, że państwo powinno interweniować w konflikty robotnicze i zapewnić takie warunki pracy, aby było ich coraz mniej. Państwo powinno zapewnić opiekę społeczeństwu jako całości, ale też dbać o interesy poszczególnych grup społecznych, w tym przypadku robotników ${ }^{38}$. Prawo ustanowione przez państwo powinno zapewnić robotnikom rozsadny minimalny standard pracy $i \dot{z y c i a^{39}}$.

Koncepcja ta potrzebowała jednak uzasadnienia w działaniach samych robotników, którzy powinni stanowić wystarczającą siłę, aby domagać się przysługujących im praw. W tym celu, uważał Ryan, niezbędne są związki zawodowe jako uczciwa reprezentacja robotników.

Zwiazek zawodowy jest konieczny nie tylko ze względu na to, że kapitat także jest zorganizowany, ale dlatego, że pojedynczy pracownik nie dysponuje sita negocjacyjna równa sile negocjacyjnej pracodawcy. (...) Nie wszyscy pracodawcy sa wystarczajaco życzliwi, aby postępować sprawiedliwie wobec pracowników, a nawet jeżeli będa tak usposobieni, nie moga spetnić swoich intencji, ponieważ ich koncepcja sprawiedliwości wobec pracowników jest z konieczności nieodpowiednia. Żadna klasa społeczna nie potrafi właściwie interpretować sprawiedliwości dla

\footnotetext{
${ }^{35}$ Idem, A Living Wage, "Common Chase?" April 1912, s. 11, ACUA John A. Ryan Collection, Box 62 (Writings, Speeches and Sermons Series), folder 11.

Szczegółowa analiza tego zagadnienia została przeprowadzona w pracy: J.A. Ryan, A Living Wage its Ethical and Economic Aspects, Macmillan \& Co., New York 1912, s. 81-122.

${ }^{36}$ Idem, Minimum Wages and Minimum Wages Board, „The Survey” 1910, September 3, s. 810 -811, ACUA John A. Ryan Collection, Box 62 (Writings, Speeches and Sermon Series), folder 10.

${ }^{37}$ Idem, A Minimum Wage by Legislation, St. Louis 1911, s. 5, ACUA John A. Ryan Collection, Box 62 (Writings, Speeches and Sermon Series), folder 11.

${ }^{38}$ Idem, The State and Labor, „America” July 3, 1921, ACUA John A. Ryan Collection, Box 63 (Writings, Speeches and Sermon Series), folder 5.

${ }^{39}$ Idem, The State and the Social Distress, „The Catholic Charities Review” 1920, vol. 4, nr 1, s. 5, ACUA John A. Ryan Collection, Box 63 (Writings, Speeches and Sermon Series), folder 4.

Na ten temat także: idem, Minimum Wage Legislation, „The Catholic World” 1913, vol. 46, s. 579, ACUA John A. Ryan Collection, Box 62 (Writings, Speeches and Sermon Series), folder 12.
} 
innej klasy społecznej. Programy reprezentacji pracowników czy związków firmowych nie moga być zastępstwem dla związu [zawodowego], dopóki pozbawia się robotników zupetnej wolności reprezentacji we wspólnych negocjacjach i dopóki nastawieni sa oni nieprzychylnie do zwiazku ${ }^{40}$.

Podsumowując encyklikę Rerum novarum, John A. Ryan stwierdził, że Leon XIII nie dał pełnej odpowiedzi, jak powinny wyglądać stosunki pracy w przemyśle, papież określił tylko pewne minimalne wymagania, przestrzeganie których nakazuje moralność chrześcijańska. Dlatego Ryan ubolewa, że tak bogate państwo, jak Stany Zjednoczone, nie stać na ustanowienie odpowiednich praw, które zapewniłyby te minimalne wymagania, a nawet więcej, ponieważ to właśnie robotnicy amerykańscy są głównymi wykonawcami sukcesu gospodarczego i należy im się za to wynagrodzenie na miarę tego sukcesu ${ }^{41}$.

Ze względu na niezwykłą aktywność w rozwiązywaniu problemów robotniczych John A. Ryan uważany jest za ojca współczesnej katolickiej myśli społecznej w USA. Przyczynił się do pogłębienia studiów nad tymi problemami i przygotował grunt pod wydanie Bishops' Program of Social Reconstruction (Programu Rekonstrukcji Społecznej przedstawionego przez Biskupów).

\section{Program biskupów amerykańskich dotyczący przebudowy społecznej}

Bishops' Program of Social Reconstruction (1919) stanowił odpowiedź na wyzwania społeczno-ekonomiczne będące wynikiem I wojny światowej. Kościół katolicki w Stanach Zjednoczonych podczas I wojny światowej zachował się w sposób bezprecedensowy. Uznał udział katolików w wojnie za patriotyczny obowiązek, jednocześnie jednak zwrócił się do władz państwowych z propozycją pomocy w minimalizowaniu uciążliwości wojny dla społeczeństwa. Najistotniejszym przejawem tej działalności było powołanie National Catholic War Council, czyli rady, która koordynowała wysiłki organizacji katolickich: społecznych, edukacyjnych i charytatywnych ${ }^{42}$.

Organizacja funkcjonowała na tyle dobrze, że episkopat amerykański uznał za stosowne kontynuowanie jej działań także po zakończeniu wojny. National Catholic War Council został przekształcony, z niewielkimi zmianami organizacyjnymi, w National Catholic Welfare Conference, która miała kontynuować dzieło akcji społecznej w czasach pokoju ${ }^{43}$.

\footnotetext{
40 Idem, The Right and Wrong of the Labor Union, maszynopis, ACUA John A. Ryan Collection, Box 62 (Writing, Speeches and Sermons Series), folder 19.

${ }^{41}$ Idem, A Constitutional Amendment for Labor Legislation, maszynopis, ACUA John A. Ryan Collection, Box 62 (Writings, Speeches and Sermon Series), folder 19.

42 Ibidem, s. 144.

${ }^{43}$ Ibidem, s. 139. Cf.: Pastoral Letter of the Archbishops and Bishops of the United States Assembled in Conference at the Catholic University of America, September 1919, The National Catholic Welfare Council, Washington 1920, s. 35.
} 
W Programie Rekonstrukcji Społecznej zaproponowano, alby przeciwdziałać skutkom wojny na przemysłowe społeczeństwo amerykańskie. Twórcami programu byli: bp Rockford Peter J. Muldoon, jako przewodniczący Komitetu Administracyjnego (Administrative Committee) National Catholic War Council, bp Toledo Joseph Schrembs, bp Tagaste Patrick J. Hayes (późniejszy abp Nowego Jorku) oraz bp Charleston William T. Russell. Autorzy programu już na wstępie zaznaczyli, że jest to tylko propozycja i może ona zostać poddana dyskusji. Jednak była ona oparta na mocnych podstawach katolickiego nauczania społecznego i jako taka godna rozważenia:

Praktyczne propozycje sa oczywiście przedmiotem dyskusji, ale wszystkie deklaracje oparte sa na wyrozumiatości i sprawiedliwości, które zawsze byty obecne $w$ nauczaniu Kościoła katolickiego, podczas gdy te propozycje sa jedynie dostosowaniem tych podstaw i tradycyjnego nauczania do warunków spolecznych i przemystowych oraz potrzeb naszych czasów ${ }^{44}$.

Biskupi przyznają, że nie są w stanie określić dokładnych potrzeb, oszacować, które z niedociągnięć systemu społecznego wymagają naprawy najpilniej oraz tego, w jaki sposób powinny zostać one naprawione. Podobna ostrożność cechowała też encyklikę Rerum novarum, której intencją nie było kształtowanie nowego systemu społeczno-ekonomicznego, a tylko wskazanie pewnych podstaw, jakimi powinni kierować się ludzie, aby zachować sprawiedliwy system społeczny.

Biskupi opracowali swój program w dużej mierze z obawy przed rozprzestrzenianiem się wśród robotników innych propozycji, m.in. Programu Rekonstrukcji Społecznej przygotowanego przez Brytyjską Partię Pracy w 1918 r., a znanego także w Stanach Zjednoczonych. Ze względu na radykalne socjalistyczne postulaty, w szczególności dotyczące nacjonalizacji przemysłu, która nie jest zgodna z zasadą nietykalności własności prywatnej, koncepcja ta została odrzucona i potępiona przez Kościół w USA.

Biskupi omówili też program przygotowany w 1919 r. przez Amerykańską Federację Pracy (American Federation of Labor, AFL). Dotyczył on trzech głównych zagadnień: prawa pracy, regulacji przemysłowych i społecznych. W zakresie prawa pracy domagano się $\mathrm{w}$ nim przede wszystkim ograniczenia czasu pracy do 8 godzin na dobę oraz tego, aby tydzień pracy nie był dłuższy niż 5,5 dnia roboczego (dla większości pracowników oznaczało to wolne niedziele i skrócenie czasu pracy w soboty). Wnioskowano o wyrównanie płac kobiet i mężczyzn, o ile wykonują tę samą pracę, zastrzeżono przy tym, że praca kobiet powinna być dostosowana do ich sił fizycznych i nie może zagrażać macierzyństwu. Postulowano zakaz zatrudniania młodzieży poniżej 16. roku życia, a do 18. roku życia tylko na 20 godzin tygodniowo ( $\mathrm{z}$ zastrzeżeniem przynajmniej 20 godzin tygodniowo na edukację $)^{45}$. Uznano, że najlepszym rozwiązaniem dla utrzymania strategicz-

\footnotetext{
${ }^{44}$ The Program of Social Reconstruction. Issued by the Four American Bishops Constituting the Administrative Committee of the National Catholic War Council [w:] The Church and the Labor, red. J.A. Ryan, J. Husslein, Macmillan \& Co., New York 1920, s. 220.

${ }^{45}$ Report of Committee of Reconstruction, American Federation of Labor (June 10-20, 1919) [w:] Labor Policies. Reconstruction Programs and Labor Economics, Federal Board for Vocational
} 
nych gałęzi przemysłu, usług i transportu (kolej, wodociągi, gazociągi, komunikacja miejska itp.) w dobrej kondycji i na odpowiednim poziomie cen będzie ich upaństwowienie. Jednocześnie pracownicy znacjonalizowanych przedsiębiorstw mieli posiadać swobodę zrzeszania się w organizacjach związkowych ${ }^{46}$. W kwestiach społecznych Amerykańska Federacja Pracy skupiła się w swoim raporcie na uregulowaniu najpilniejszych potrzeb: m.in. wszyscy robotnicy, zarówno wykwalifikowani, jak i niewykwalifikowani, powinni otrzymywać wynagrodzenie umożliwiające utrzymanie ich rodzin na godziwym poziomie, który zdefiniowano w następujący sposób: (...) płaca, która umożliwi pracownikowi i jego rodzinie zycie $w$ zdrowiu $i$ dostatku, zapewni zabezpieczenie na czas choroby $i$ na starość, pozwoli we wszelkich okolicznościach rozwijać to, co najlepsze w ludziach ${ }^{47}$. W celu zapewnienia robotnikom i ich rodzinom odpowiednich warunków mieszkaniowych starano się nakłonić rząd do wprowadzenia planu budowy tanich mieszkań i domów oraz uruchomienia tanich kredytów, za które robotnicy mogliby je kupować ${ }^{48}$.

Biskupi uznali program Amerykańskiej Federacji Pracy za stosunkowo nowoczesny i rozsądny, jednakże jeden element budził ich zastrzeżenia. Dla pozyskania większych środków na zrealizowanie swoich postulatów AFL proponowała nałożenie dodatkowego podatku od gruntów oraz specjalnego podatku od nieużytków. Odmowa lub niemożność zapłacenia tychże podatków mogła prowadzić do konfiskat, biskupi zatem nie mogli przyjąć takiego rozwiązania ${ }^{49}$.

Jedyną propozycją naprawy stosunków przemysłowych wniesioną przez amerykańskich pracodawców był Social Reconstruction Program, przygotowany przez National Chamber of Commerce ${ }^{50}$. Nie wydawał się on biskupom interesujący. Oprócz pustych deklaracji o przyjaźni i wspólnocie interesów pomiędzy pracodawcami i robotnikami ograniczał się do potępienia polityki rządu w kwestii monopoli, m.in. złagodzenia Sherman Anti-Trust Law. W programie tym zauważono jednakże pewien postęp, jeśli chodzi o stosunek pracodawców do pracowników. Polegał on na uznaniu prawa pracowników do zakładania niezależnych związków zawodowych, stworzeniu ponadpartyjnego organu, który monitorowałby problemy robotnicze i starał się je rozwiązywać ponad podziałami politycznymi, postulowaniu zapewnienia robotnikom domów i godziwych warunków socjalnych. Godną uwagi inicjatywą był postulat szukania oszczędności w przemyśle $\mathrm{w}$ procesie produkcji i dystrybucji, a dopiero w ostateczności przez redukcję płac pracowników ${ }^{51}$.

Po przeanalizowaniu wielu programów przygotowanych zarówno w Stanach Zjednoczonych, jak i w Wielkiej Brytanii, biskupi amerykańscy, którzy kierowali

\footnotetext{
Education Employment Management Section, Washington 1919, s. 1-(2), ACUA John A. Ryan Collection, Box 56 (Reference Files Series), folder 8 (Post World War I Reconstruction, Bishop's Program).

${ }^{46}$ Ibidem, s. 1-(2).

${ }^{47}$ Ibidem, s. 1-(1).

${ }^{48}$ Ibidem, s. 1-(3).

${ }^{49}$ The Program of the Social Reconstruction..., s. 223.

${ }^{50}$ National Chamber of Commerce (Narodowa Izba Handlu), program został przedstawiony na zjeździe organizacji w Atlantic City w grudniu 1918 r.

${ }^{51}$ The Program of the Social Reconstruction ..., s. 224.
} 
wydziałem społecznym NCWC, uznali za konieczne stworzenie propozycji, która byłaby zgodna $\mathrm{z}$ doktryną katolicką i mogłaby być rozpowszechniana wśród robotników. Program ten, jak wcześniej wspomniano, miał być swego rodzaju przewodnikiem dla rozstrzygnięcia kwestii robotniczej w duchu chrześcijańskiej sprawiedliwości, wypływającej z nauczania zawartego w encyklice Rerum novarum oraz publikacjach Johna A. Ryana.

W programie zaznaczono, że najbardziej paląca kwestia to przywrócenie do pracy w przemyśle zdemobilizowanych żołnierzy:

Podstawowym problemem $w$ procesie przebudowy [społecznej] jest przemystowe rozdysponowanie zdemobilizowanych żotnierzy i marynarzy. Większość z nich bez watpienia powróci do swoich zawodów. Jednakże duża część albo zastanie wcześniejsze miejsce już zajęte, albo rozważy możliwość atrakcyjniejszego zatrudnienia. Rozwiazaniem tej sytuacji jest ulokowanie tych ludzi na farmach ${ }^{52}$.

Alternatywnym rozwiązaniem była możliwość zatrudnienia ich przy dużych przedsięwzięciach finansowanych $\mathrm{z}$ budżetu państwa, np.: nawadnianiu terenów jałowych, osuszaniu bagien, wycince lasów. Przygotowane w ten sposób tereny miały zostać przeznaczone pod uprawę, zdemobilizowani żołnierze mieli możliwość zakładania na nich nowych farm, chociaż bardziej preferowano zakładanie kolonii rolniczych. Rozwiązanie takie spowodowałoby, według autorów programu, obniżenie kosztów życia ze względu na znaczny wzrost podaży produktów spożywczych, a przez to spadek cen. Sytuacja miała stopniowo powracać do normy (czyli stanu sprzed I wojny światowej) i zatrudnieni w rolnictwie zdemobilizowani żołnierze powinni z czasem powrócić do przemysłu. Jednak praktycznymi rozwiązaniami tej operacji obarczono instytucje państwowe, w szczególności Federalny Urząd Pracy ${ }^{53}$.

Podczas wojny wiele zawodów, wykonywanych wcześniej wyłącznie przez mężczyzn, przejęły kobiety. Biskupi uznali, że należy uczynić wszystko, aby kobiety opuściły miejsca pracy zagrażające ich zdrowiu i moralności:

Jedna ogólna zasada jest jasna: żadna z robotnic nie powinna pozostać na stanowisku pracy, które jest szkodliwe dla zdrowia i moralności. Kobiety powinny zniknać tak szybko, jak to możliwe, z takich profesji, jak: prowadzenie i obstuga tramwajów, czyszczenie lokomotyw oraz liczne inne czynności, do których ich warunki fizyczne i psychiczne czynia je niezdolnymi ${ }^{54}$.

Zwolniłoby się wiele miejsc pracy dla zdemobilizowanych żołnierzy, kobiety powróciłyby do lżejszej pracy lub nawet zrezygnowały $\mathrm{z}$ pracy $\mathrm{w}$ przemyśle i poświęciły rodzinie, na czym biskupom szczególnie zależało.

Kolejną troską biskupów była kwestia płac oraz warunków życia robotników. Podczas wojny płace robotników znacznie wzrosły (było to jednak powiązane ze wzrostem kosztów życia i ogólną inflacją). Istniały uzasadnione obawy, że wraz

\footnotetext{
${ }^{52}$ Ibidem, s. 227.

53 Ibidem, s. 228.

${ }^{54}$ Ibidem, s. 228.
} 
z przestawieniem dużej części gospodarki amerykańskiej na produkcję cywilną spadną ceny produktów codziennego użytku i żywności, a z czasem zmaleją także płace. Zaapelowano, aby utrzymać płace na takim samym poziomie, wspomniano także o konieczności wprowadzenia płacy minimalnej. Biskupi przyjęli takie pojęcie płacy minimalnej, jak rozumiał ją John A. Ryan, tzn. jako sprawiedliwe minimum, niezbędne do utrzymania rodziny. Jednak minimalna sprawiedliwa płaca nie jest wystarczająca dla prawidłowego rozwoju rodziny, miała ona być jedynie granicą, poniżej której pracodawcy nie wolno schodzićs5:

Początkowo płaca minimalna dla robotników powinna wystarczać jedynie na bieżace potrzeby rodziny, jednak powinna ona stopniowo wzrastać, aż do momentu, gdy będzie odpowiednia, aby sprostać także przyszlym potrzebom. Oznacza to, że ostatecznie powinna być wystarczajaco wysoka, aby umożliwić pewne oszczędności, które sa konieczne dla zabezpieczenia pracownika i jego rodziny od choroby, wypadku, inwalidztwa oraz starości ${ }^{56}$.

Godne uwagi było podjęcie przez biskupów kwestii, która była jednym z najciekawszych postulatów Leona XIII zawartych w encyklice Rerum novarum - współudziału pracowników w zarządzaniu przedsiębiorstwami i współwłasności przedsiębiorstw, które ich zatrudniają. W warunkach amerykańskich, aby wprowadzić te postulaty w życie, należało rozwiązać kwestię trustów. Pozostawało to wyłącznie w gestii państwa - tylko przez federalne ustawodawstwo można był rozwiązać problem monopoli. Umożliwienie przedstawicielom legalnie działających związków zawodowych współudziału w zarządzaniu przedsiębiorstwem zapewniłoby nić porozumienia z pracodawcami. Przyczyniłoby się także do zwiększenia wydajności i współodpowiedzialności pracowników za własne miejsce pracy ${ }^{57}$. Sprawa udziału robotników we własności przedsiębiorstw została potraktowana w programie biskupów dość ogólnikowo. Wspomniano, że sprawiedliwość wymaga, aby większość posiadała przynajmniej część narzędzi, którymi pracuje. Przyczyniłoby się to przynajmniej do częściowego zmniejszenia olbrzymiej dysproporcji pomiędzy majątkiem garstki bogatych przemysłowców a milionami ubogich robotników. Jednocześnie stanowczo zaznaczono, że nie chodzi o własność kolektywną, a rozłożenie własności na większą liczbę osób, pozostawiając ją w indywidualnych rękach. Rozwiązanie takie rozładowałoby napięcia społeczne i ustrzegłoby przed groźbą rewolucji ${ }^{58}$.

Podsumowując swój program, biskupi stwierdzili, że żadna próba uporządkowania sytuacji społecznej nie zakończy się sukcesem, jeżeli nie będzie oparta o podstawy sprawiedliwości społecznej zawarte w doktrynie chrześcijańskiej:

Zmiany w naszym systemie ekonomicznym i politycznym będa jedynie częściowe i mało efektywne, jeżeli nie zostana wzmocnione chrześcijańskim spojrzeniem na prace i dobro. Ani umiarkowane reformy zawarte w tym dokumencie, ani żaden

\footnotetext{
${ }^{55}$ Ibidem, s. 230.

${ }^{56}$ Ibidem, s. 233.

${ }^{57}$ Ibidem, s. 234-235.

${ }^{58}$ Ibidem, s. 237-238.
} 
inny program ulepszeń nie zagwarantuje rozsadnych efektów bez zmian $w$ obu duchach: pracowników i przemystowców. Robotnicy musza zrozumieć, że zawdzięczaja pracodawcom i spoleczeństwu uczciwy dzień pracy $w$ zamian za godziwe wynagrodzenie, $i$ że warunki takie nie moga być stale zapewnione, dopóki nie wykorzenia żadzy otrzymania maksymalnej zapłaty $w$ zamian za minimalna pracę. Kapitaliści (...) musza nauczyć się prawdy, która dawno zapomnieli, że bogactwo jest odpowiedzialnościa, że wytwarzanie zysku nie jest podstawowym uzasadnieniem przedsiębiorczości i że istnieja uczciwe zyski, uczciwe interesy i uczciwe place ${ }^{59}$.

Przyjęcie takiego rozumowania zmieniłoby obopólne postrzeganie robotników i kapitalistów. Jedni i drudzy są ludźmi i jak ludzie powinni być traktowani. Przedsiębiorcy mają prawo czerpać zyski z interesów, jednak nie mogą zapominać, że nie może się to odbywać kosztem pracowników, ponieważ urąga to prawom ludzkim i zasadom chrześcijańskim.

Program biskupów został bardzo dobrze przyjęty wśród amerykańskich katolików. Był podsumowaniem wielu lat pracy nad kwestią społeczną i robotniczą w Stanach Zjednoczonych i przysporzył Kościołowi w tym kraju wiele sympatii ze strony robotników. Wskazano jednak na nowe zagrożenia i problemy powojennej Ameryki, które należy rozwiązać:

Gtębszy i bardziej wszechstronny jest ferment $w$ duszach ludzi podatnych na agitacje nie tylko przeciwko błędom $w$ dziataniu obecnego porzadku, ale także przeciwko samemu porzadkowi, jego podstawom i zatożeniom. Ludzie tak usposobieni widza tylko fakty - nierówny podziat dóbr, władzy i światowych korzyści - i buntuja się przeciwko tym faktom. Jednak nie dostrzegaja prawdziwych przyczyn powodujacych te efekty, a tym bardziej odpowiednich środków, dzięki którym i przyczyny, $i$ ich rezultaty moga zostać usunięte. W zwiazku z tym przy próbach zaradzenia stosowane sq metody, które powoduja niepowodzenie i dalsza beznadziejna dezorientacje $e^{60}$.

Biskupi zalecają, aby uznać nadrzędne prawo boskie jako główny wyznacznik zasad życia społecznego, politycznego i ekonomicznego ${ }^{61}$. Poddanie się chrześcijańskiemu duchowi sprzyjać ma wzajemnemu porozumieniu i sprawiedliwości62.

Na straży wolności powinno stać państwo, które musi zrozumieć, jakie korzyści wypływają z popierania religii wśród własnych obywateli. Sprawiedliwe państwo jest dla obywateli gwarancją wolności ${ }^{63}$. Podobnie jak uczynił to Leon XIII, biskupi amerykańscy podkreślili, że kluczem do rozwiązania problemu robotniczego jest uszanowanie godności ludzkiej:

Moralna wartość człowieka i godność pracy ludzkiej sa głównymi punktami. Pozwólmy, aby byty decydującymi podmiotami w przemyśle, a pójda znacznie dalej niż zapobiegawcze dyskusje. Przez traktowanie robotnika przede wszystkim jako

\footnotetext{
${ }^{59}$ Ibidem, s. 239.

${ }^{60}$ Pastoral Letter of the Archbishops and Bishops of the United States Assembled..., s. 38.

${ }^{61}$ Ibidem, s. 42-43.

62 Ibidem, s. 45.

${ }^{63}$ Ibidem, s. 47.
} 
człowieka pracodawca uczyni go lepszym pracownikiem; przez respektowanie jego własnej godności moralnej jako człowieka wymusi na pracownikach szacunek do pracodawcy $i$ do społeczności $i^{64}$.

Program społeczny biskupów spotkał się z bardzo przychylnym przyjęciem także poza Kościołem, komentatorzy podkreślali jego całościowe podejście do problemu robotniczego i poruszenie wszystkich istotnych kwestii ${ }^{65}$. Uznano, że Kościół katolicki w Stanach Zjednoczony pretenduje do roli „,moralnego policjanta kapitalizmu", przed zakusami którego broni robotników ${ }^{66}$. John A. Ryan zauważył, że encyklikę Rerum novarum można traktować jako zbiór propozycji, które zostały przełożone na język konkretnych rozwiązań przez program rekonstrukcji społecznej67. Dodał, że rozwiązania te nie są rewolucyjne, a po prostu ustanawiają pewne normy traktowania robotników w sposób sprawiedliwy i zgodny z moralnością ${ }^{68}$.

Głosy krytyczne na temat programu biskupów dotyczyły jednostronności w rozważaniu problemów, braku otwartego i nowego spojrzenia na kwestie społeczne ${ }^{69}$. Brakowało też przełożenia propozycji na rzeczywiste warunki panujące w przemyśle w owym czasie ${ }^{70}$. Jednak, co należy podkreślić, wiele postulatów znalazło odzwierciedlenie w ustawodawstwie New Deal. Przede wszystkim państwo podjęło trud opieki nad robotnikami w okresie kryzysu. Zorganizowano system prac interwencyjnych, w tym celu powołano odpowiednie instytucje: Civilian Conservation Corps, Public Works Administration, Works Progress Administration. Wprowadzono płacę minimalną, system ubezpieczeń społecznych i wiele innych regulacji dotyczących pracy i warunków bytowych robotników ${ }^{71}$.

\section{Podsumowanie}

Trudno określić bezpośredni wpływ interpretacji encykliki Rerum novarum przez Johna A. Ryana na stosunki pracy w Stanach Zjednoczonych Ameryki. Nie ma jednak wątpliwości, że przyczynił się on do szerokiego rozpropagowania idei zawartych w encyklice wśród amerykańskich katolików. Fakt, że zostały one w pewnym

\footnotetext{
${ }^{64}$ Ibidem, s. 60.

${ }^{65}$ M.in.: płacy minimalnej, ubezpieczeń społecznych, lepszych warunków pracy, udziału w dochodach przedsiębiorstw. Cf. J. Piekoszewski, Katolicyzm amerykański, Redakcja Wydawnictw KUL, Lublin 1989, s. 115-116.

${ }^{66}$ W. Hard, The Catholic Church Accepts the Challenge, „Metropolitan” 1920, January, s. 25, kopia w ACUA John A. Ryan Collection, Box 57 (Reference Files Series), folder 3.

${ }^{67}$ J.A. Ryan, The Church and Economics, „America” April 17, 1920, s. 593-594, ACUA John A. Ryan Collection, Box 63 (Writing, Speeches, and Sermons series), folder 4.

${ }^{68}$ Idem, Labor's Program of Reconstruction, kopia artykułu, źródło nieokreślone, ACUA John A. Ryan Collection, Box 62 (Writings, Speeches and Sermons Series), folder 15.

${ }^{69}$ R. Swing, The Catholic View of Reconstruction, „The Nation” March 29, 1919, s. 467, ACUA John A. Ryan Collection, Box 57 (Reference Files Series), folder 4.

${ }^{70}$ P.T. Sherman, Catholic „Social Reconstruction Program” Analyzed, „The National Civic Federation Review” 1920, September 25, s. 5, ACUA John A. Ryan Collection, Box 57 (Reference Files Series), folder 4 .

${ }^{71}$ Z. Lewicki, op. cit., s. 564, 567-570.
} 
stopniu wprowadzone do ustawodawstwa New Deal, może świadczyć o wpływie Kościoła katolickiego na rządzących. Szczególnie niektóre ustawy bliskie były postulatom Rerum novarum i koncepcjom Johna A. Ryana: National Industrial Recovery Act, Social Security Act, National Labor Relations Act, Fair Labor Standards Act. Wprowadzały one nowe reguły dotyczące stosunków pracy i organizacji życia gospodarczego w Stanach Zjednoczonych Ameryki. Niektóre z nich zgodne były z propozycjami Johna A. Ryana: prawo robotników do swobodnego zrzeszania się, zatrudnianie bezrobotnych przy robotach publicznych, wprowadzenie ubezpieczeń pracowniczych od wypadków i bezrobocia, emerytury, ustanowienie National Labor Relations Board - ustawy mającej stać na straży praw pracowniczych, wreszcie wprowadzenie płacy minimalnej i ograniczenie czasu pracy.

\section{Bibliografia}

Abell A.I., Monsignor John A. Ryan: An Historical Appreciation, „The Review of Politics” 1946, vol. 8, nr 1, ACUA John A. Ryan Collection, Box 58 (Reference Files Series), folder 15 (Biographical articles).

Broderick F.L., Right Reverend New Dealer: John A. Ryan, Macmillan \& Co., New York 1963.

Catholicus [John A. Ryan], A Catholic View of Socialism, „International Socialist Review” 1901, October, kopia, ACUA John A. Ryan Collection, Box 62 (Writings, Speeches and Sermon Series), folder 9.

Chałasiński J., Kultura amerykańska. Formowanie się kultury narodowej w Stanach Zjednoczonych Ameryki, Ludowa Spółdzielnia Wydawnicza, Warszawa 1970.

Chinnici J.P., Spiritual Capitalism and the Culture of American Catholicism, „U.S. Catholic Historian" 1986, vol. 5, nr 2, s. 131-161.

Faulkner H.U., American Political and Social History, Houghton Mifflin, New York 1943.

Faulkner H.U., M. Starr, Labor in America, Oxford Book Co., New York 1958.

Gabaccia D.R., Imigracja do Stanów Zjednoczonych, 1848-1917 [w:] Historia Stanów Zjednoczonych Ameryki, t. 3 (1848-1917), red. W. Nugent, H. Parafinowicz, PWN, Warszawa 1995, s. 185-209.

Hard W., The Catholic Church Accepts the Challenge, „Metropolitan” 1920, January, kopia w ACUA John A. Ryan Collection, Box 57 (Reference Files Series), folder 3.

Hourwich I.A., Immigration and Labor. The Economic Aspects of European Immigration to the United States, G.P. Putnam's Sons, New York, London 1912.

Ireland J., The Catholic Church Equally Opposed to Anarchy and to Despotism, the Guardian of Society, the Defender of True Liberty [w:] The Memorial Volume. A History of the Third Plenary Council of Baltimore (November 9 - December 7, 1884), The Baltimore Publishing Co., Baltimore 1885, s. 11-32.

Konstytucja Stanów Zjednoczonych Ameryki, wstęp i thum. M. Król-Bogomilska, Beartig, Warszawa 1992.

Leszczyński A., Pieniadze za nic, „Polityka” 2015, nr 14, s. 53-55. 
Lewicki Z., Historia cywilizacji amerykańskiej. Era konsolidacji 1861-1945, Wyd. Naukowe Scholar, Warszawa 2012.

Luce S., Living Wage Policies and Campaigns: Lessons from the United States, „International Journal of Labour Research" 2012, vol. 4, nr 1, s. 11-26.

Małajny R.M., „Mur separacji” - państwo a Kościót w Stanach Zjednoczonych Ameryki, Wyd. Uniwersytetu Śląskiego, Katowice 1992.

McShane J.M., Sufficiently Radical. Catholicism, Progressivism, and the Bishops' Program of 1919, Catholic Univ. Press, Washington 1986.

Napierała P., In God We Trust. Religia w sferze publicznej USA, Księgarnia Akademicka, Kraków 2015.

Pastoral Letter of the Archbishops and Bishops of the United States Assembled in Conference at the Catholic University of America, September 1919, The National Catholic Welfare Council, Washington 1920.

Piekoszewski J., Katolicyzm amerykański, Redakcja Wydawnictw KUL, Lublin 1989.

The Program of Social Reconstruction. Issued by the Four American Bishops Constituting the Administrative Committee of the National Catholic War Council [w:] The Church and the Labor, red. J.A. Ryan, J. Husslein, Macmillan \& Co., New York 1920.

Purcell R.J., John A. Ryan. Prophet of Social Justice, „Studies” 1946, June, ACUA, Ryan Collection, Box 58 (Reference File Series), folder 15 (Biographical articles).

Rayback J.G., A History of American Labor. Expanded and Updated, The Free Press, New York 1966.

Report of Committee of Reconstruction, American Federation of Labor (June 10-20, 1919) [w:] Labor Policies. Reconstruction Programs and Labor Economics, Federal Board for Vocational Education Employment Management Section, Washington 1919, s. 1-(2), ACUA John A. Ryan Collection, Box 56 (Reference Files Series), folder 8 (Post World War I Reconstruction, Bishop's Program).

Ryan J.A., A Constitutional Amendment for Labor Legislation, maszynopis, ACUA John A. Ryan Collection, Box 62 (Writings, Speeches and Sermon Series), folder 19.

Ryan J.A., A Living Wage, „Common Chase?” 1912, April, s. 11, ACUA John A. Ryan Collection, Box 62 (Writings, Speeches and Sermons Series), folder 11.

Ryan J.A., A Living Wage its Ethical and Economic Aspects, Macmillan \& Co., New York 1912.

Ryan J.A., A Minimum Wage by Legislation, St. Louis 1911, ACUA John A. Ryan Collection, Box 62 (Writings, Speeches and Sermon Series), folder 11.

Ryan J.A., A Social Doctrine in Action. A Personal History, Harper and Brothers, New York, London 1941.

Ryan J.A., Church and Economic Problems, maszynopis, ACUA John A. Ryan Collection, Box 62 (Writings, Speeches and Sermons Series), folder 16.

Ryan J.A, Labor's Program of Reconstruction, kopia artykułu, źródło nieokreślone, ACUA John A. Ryan Collection, Box 62 (Writings, Speeches and Sermons Series), folder 15.

Ryan J.A., Minimum Wages and Minimum Wages Board, „The Survey” 1910, September, s. 810-811, ACUA John A. Ryan Collection, Box 62 (Writings, Speeches and Sermon Series), folder 10. 
Ryan J.A., Minimum Wage Legislation, „The Catholic World” 1913, vol. 46, ACUA John A. Ryan Collection, Box 62 (Writings, Speeches and Sermon Series), folder 12.

Ryan J.A., The Catholic Church and Public Ownership, maszynopis, ACUA John A. Ryan Collection, Box 63 (Writings, Speeches and Sermons Series, 1910-1928), folder 2.

Ryan J.A., The Church and Economics, „America” 1920, April 17, ACUA John A. Ryan Collection, Box 63 (Writing, Speeches, and Sermons series), folder 4.

Ryan J.A., The Church and the Radical Social Movements, maszynopis, ACUA John A. Ryan Collection, Box 63 (Writings, Speeches and Sermons Series), folder 3.

Ryan J.A., The Church and the Social Question, maszynopis, ACUA John A. Ryan Collection, Box 63 (Writings, Speeches and Sermons Series), folder 16.

Ryan J.A., The Right and Wrong of the Labor Union, maszynopis, ACUA John A. Ryan Collection, Box 62 (Writing, Speeches and Sermons Series), folder 19.

Ryan J.A., The State and Labor, „America” 1912, July 3, ACUA John A. Ryan Collection, Box 63 (Writings, Speeches and Sermon Series), folder 5.

Ryan J.A., The State and the Social Distress, „The Catholic Charities Review” 1920, vol. 4, nr 1, ACUA John A. Ryan Collection, Box 63 (Writings, Speeches and Sermon Series), folder 4.

Ryan J.A., The Study of Social Problems in the Seminary, „Proceedings of the Catholic Educational Association” 1908, ACUA John A. Ryan Collection, Box 62 (Writings, Speeches and Sermon Series 1900-1919), folder 10.

Scheiber H.N., H.G. Vatter, H.U. Faulkner, American Economic History, Harper and Row, New York 1976.

Sherman P.T., Catholic „Social Reconstruction Program” Analyzed, „The National Civic Federation Review" 1920, September 25, ACUA John A. Ryan Collection, Box 57 (Reference Files Series), folder 4.

Sullivan P.J., Catholic Labor Priests in the United States. A $20^{\text {th }}$ Century Story of Solidarity, vol. 1, Five Giants in the Bishops' Social Action Department Among More Than Four Hundred U. S. Catholic Labor Priests, Pacem in Terris Press, Washington D.C. 2014.

Swing R., The Catholic View of Reconstruction, „The Nation” 1919, March 29, ACUA John A. Ryan Collection, Box 57 (Reference Files Series), folder 4.

Walaszek A., Polscy robotnicy, praca i zwiazki zawodowe w Stanach Zjednoczonych Ameryki, 1880-1922, Ossolineum, Wrocław-Warszawa-Kraków-Gdańsk-Lódź, 1988.

Whittelsey S.S., Massachusetts Labor Legislation [w:] Trade Unionism and Labor Problems, red. J.R. Commons, Ginn and Co., Boston, New York, Chicago, London, 1905, s. 482-508.

Workers' World. Kinship, Community, and Protest in an Industrial Society 1900-1940, red. J. Bodnar, John Hopkins Univ. Press, Baltimore 1982. 